\title{
Syntheses, Crystal Structures, and Antitumor Activities of Copper(II) and Nickel(II) Complexes with 2-((2-(Pyridin-2-yl)hydrazono)methyl)quinolin-8-ol
}

\author{
Qi-Yuan Yang ${ }^{\dagger}$, Qian-Qian Cao ${ }^{\dagger}$, Qi-Pin Qin ${ }^{\circledR}$, Cai-Xing Deng, Hong Liang \\ and Zhen-Feng Chen *
}

State Key Laboratory for Chemistry and Molecular Engineering of Medicinal Resources, School of Chemistry and Pharmacy, Guangxi Normal University, 15 Yucai Road, Guilin 541004, China;

2016110029@stu.gxnu.edu.cn (Q.-Y.Y.); 2014011049@stu.gxnu.edu.cn (Q.-Q.C.);

2014110004@stu.gxnu.edu.cn (Q.-P.Q.); 2016010981@stu.gxnu.edu.cn (C.-X.D.); hliang@gxnu.edu.cn (H.L.)

* Correspondence: chenzf@gxnu.edu.cn; Fax: +86-773-2120958

+ These authors contributed equally to this work.

Received: 12 May 2018; Accepted: 5 June 2018; Published: 26 June 2018

\begin{abstract}
Two transition metal complexes with 2-((2-(pyridin-2-yl)hydrazono)methyl)quinolin-8-ol $(\mathrm{L}),\left[\mathrm{Cu}(\mathrm{L}) \mathrm{Cl}_{2}\right]_{2}(\mathbf{1})$ and $\left[\mathrm{Ni}(\mathrm{L}) \mathrm{Cl}_{2}\right] \cdot \mathrm{CH}_{2} \mathrm{Cl}_{2}(2)$, were synthesized and fully characterized. Complex $\mathbf{1}$ exhibited high in vitro antitumor activity against SK-OV-3, MGC80-3 and HeLa cells with $\mathrm{IC}_{50}$ values of $3.69 \pm 0.16,2.60 \pm 0.17$, and $3.62 \pm 0.12 \mu \mathrm{M}$, respectively. In addition, complex 1 caused cell arrest in the S phase, which led to the down-regulation of Cdc25 A, Cyclin B, Cyclin A, and CDK2, and the up-regulation of p27, p21, and p53 proteins in MGC80-3 cells. Complex 1 induced MGC80-3 cell apoptosis via a mitochondrial dysfunction pathway, as shown by the significantly decreased level of bcl-2 protein and the loss of $\Delta \psi$, as well as increased levels of reactive oxygen species (ROS), intracellular $\mathrm{Ca}^{2+}$, cytochrome $\mathrm{C}$, apaf-1, caspase-3, and caspase-9 proteins in MGC80-3 cells.
\end{abstract}

Keywords: quinolinyl hydrazine; copper(II) complex; cytotoxicity; apoptosis

\section{Introduction}

Numerous platinum(II) complexes have been successfully used for the treatment of different types of cancers [1]. Platinum complexes stand out among chemotherapeutic agents for its high efficacy in combination therapy. However, they also show drawbacks like toxicity and drug resistance [2]. Especially, the clinical use of cisplatin is severely limited by its unwanted side effects, including ototoxicity and nephrotoxicity, which reduce patient tolerance during treatment and interfere with the long-term quality of life [3]. Therefore, it is necessary to explore other nonplatinum complexes that could offer high efficacy with fewer side effects.

Many studies show that the copper and nickel complexes play an important role in the endogenous oxidative DNA damage associated with aging and cancer [4-8]. For example, complexes with $\mathrm{Cu}(\mathrm{II})$ ion show high DNA binding and DNA cleavage activities [9], and copper complexes induced reversible condensation of DNA and apoptosis in osteosarcoma MG-63 cell lines [10]. Many nickel complexes bearing biological activity have been reported including $\mathrm{Ni}(\mathrm{II})$ complexes with antitumor activity [11,12]. Nickel complexation with lidocaine enhances the DNA binding affinity, DNA cleavage activity, and cytotoxic properties of lidocaine [13]; Nickel complexes also show considerable cytotoxic activity against the human hepatocarcinoma cells (Hep-G2), human leukemic cells (HL-60), and human prostatic carcinoma cells (PC-3) [14]. Therefore, the synthesis and biological testing of copper and nickel complexes have become an important area of current bioinorganic chemistry research [15-17]. 
The compound 8-Hydroxyquinoline (HQ) has attracted considerable interest as a privileged structure (Scheme 1), and 8-hydroxyquinoline derivatives (HQs) have been explored for a broad range of biological applications [18], such as metal-chelators for neuroprotection, chelators of metalloproteins, inhibitors of 2OG-dependent enzymes, Mycobacterium tuberculosis inhibitors, botulinum neurotoxin inhibitors and anticancer, anti-HIV, antifungal, antileishmanial, and antischistosomal agents [19-21]. The HQs with anticancer or anti-Alzheimer activities include mainly halogenated derivatives [22,23], diperazino and alkyno derivatives [24,25], nitro derivatives [26-28], carboxylic and carboxamido derivatives [29-31], amino and imino derivatives [32,33], sulfoxine and sulfonamide derivatives [34-36], Bis- and poly-HQs [37,38], HQ bioconjugates [39-41], and other HQ derivatives [42]. In addition, it is well known that quinolinylhydrazones show various important biological activities and the quinoline ring plays an important role in the development of new anticancer agents [43-47]. For example, the quinolinylhydrazones exhibit significant cytotoxicity in comparison with similar reported systems and the apoptosis induction in MCF-7 cancer cells increased when it was coordinated with the gold nanoparticle surface [48]. Recently, the synthesis of 2-((2-(pyridin-2-yl)hydrazono)methyl)quinolin-8-ol (L) was reported [49]. The metal complexes of HQs show enhanced tumor cytotoxicity [50-56], including ruthenium [50,51], gold [52], platinum [53], copper [43,48,49], and vanadium [44] complexes. However, there are few reports on the synthesis and antitumor activity of $\mathrm{Cu}$ (II) and $\mathrm{Ni}$ (II) complexes. Chan et al. found that 8-hydroxy-2-quinolinecarbaldehyde (Scheme 1) showed the highest in vitro cytotoxicity against the human cancer cell lines, including MDA231, T-47D, Hs578t, SaoS2, K562, SKHep1, and Hep3B [42].

Therefore, as part of our continuing work on the synthesis, characterization and medicinal application of metal complexes with HQ [45-47], we report the synthesis and characterization of $\mathrm{Cu}$ (II) and $\mathrm{Ni}(\mathrm{II})$ complexes with 2-((2-(pyridin-2-yl)hydrazono)methyl)quinolin-8-ol (L) and the in vitro cytotoxicities against seven tumor cells and their antitumor mechanism.<smiles>Oc1cccc2cccnc12</smiles>

HQ<smiles>N/N=C/c1ccc2cccc(O)c2n1</smiles>

$\mathrm{QH}$<smiles>O=Cc1ccc2cccc(O)c2n1</smiles>

8-hydroxy-2-quinolinecarbaldehyde<smiles>Oc1cccc2ccc(/C=N/Nc3ccccn3)nc12</smiles>

L

Scheme 1. The structures of 8-hydroxyquinoline (HQ), quinolinyl hydrazine $(\mathrm{QH})$ and L.

\section{Results}

\subsection{Synthesis}

As outlined in Scheme 2, complexes 1, 2 were synthesized by the reaction of $\mathrm{L}$ with $\mathrm{CuCl}_{2} \cdot 2 \mathrm{H}_{2} \mathrm{O}$ and $\mathrm{NiCl}_{2} \cdot 6 \mathrm{H}_{2} \mathrm{O}$ in hot methanol, respectively. They were satisfactorily characterized by mass spectrometry (MS), elemental analysis (EA), infrared spectroscopy (IR), and single-crystal X-ray diffraction analysis. The absorptions around $1550-1650 \mathrm{~cm}^{-1}$ of the IR (Figures S3-S5) were assigned to the imine bond stretching vibrations of L. The imine bonds of complexes $\mathbf{1}$ and $\mathbf{2}$ underwent a left-shift of 10-60 $\mathrm{cm}^{-1}$ upon coordination, indicating the participation of this group in coordination. The single-crystal structure analysis suggested that the $\mathrm{Cu}(\mathrm{II})$ complex was $\left[\mathrm{Cu}(\mathrm{L}) \mathrm{Cl}_{2}\right]_{2}(\mathbf{1})$ and the $\mathrm{Ni}(\mathrm{II})$ complex was $\left[\mathrm{Ni}(\mathrm{L}) \mathrm{Cl}_{2}\right] \cdot \mathrm{CH}_{2} \mathrm{Cl}_{2}$ (2). 


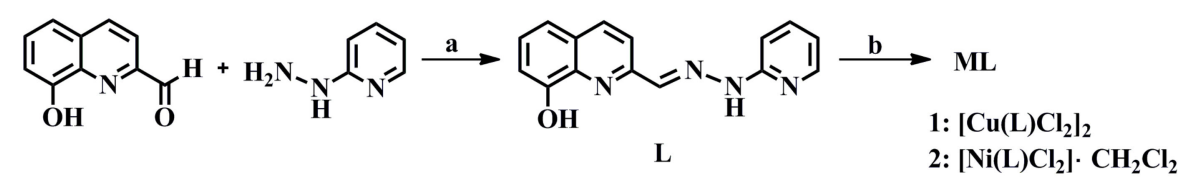

Scheme 2. The synthetic routes for ligand (L) and its metal complexes $\mathbf{1}$ and $\mathbf{2}$. Reagents are as follows: (a) $\mathrm{EtOH}$, r.t, 16 h; (b) $\mathrm{CuCl}_{2}$ or $\mathrm{NiCl}_{2}, \mathrm{MeOH} / \mathrm{CH}_{2} \mathrm{Cl}_{2}$.

\subsection{Crystal Structures of Complexes $\mathbf{1}$ and $\mathbf{2}$}

The crystal data and refinement details of complexes $\mathbf{1}$ and $\mathbf{2}$ are summarized in Table S1 (Supporting Information), and the selected bond lengths and angles are listed in Tables S2 and S3. The crystal structures of complexes $\mathbf{1}$ and $\mathbf{2}$ are shown in Figures 1 and 2. Complexes $\mathbf{1}$ and $\mathbf{2}$ have different coordination pattern. Complex 1 was a dinuclear $\mathrm{L}-\mathrm{Cu}-\mathrm{Cl}-(\mu-\mathrm{Cl})_{2}-\mathrm{Cu}-\mathrm{Cl}-\mathrm{L}$ complex, and the $\mathrm{Cu}(\mathrm{II})$ ions were coordinated by three $\mathrm{Cl}$ and two $\mathrm{N}$ atoms from $\mathrm{L}$ in a distorted square pyramidal geometry.

In complex 2, the central $\mathrm{Ni}^{\mathrm{II}}$ adopted an approximately five-coordinated tetragonal pyramidal geometry.

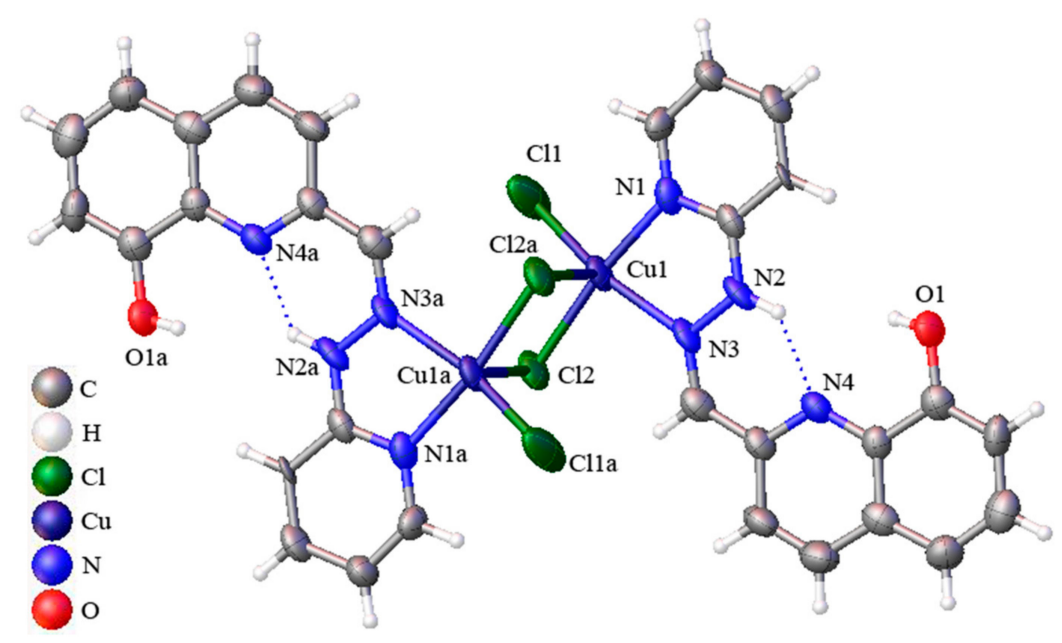

Figure 1. The crystal structure of $\mathrm{Cu}(\mathrm{II})$ complex $\mathbf{1}$.

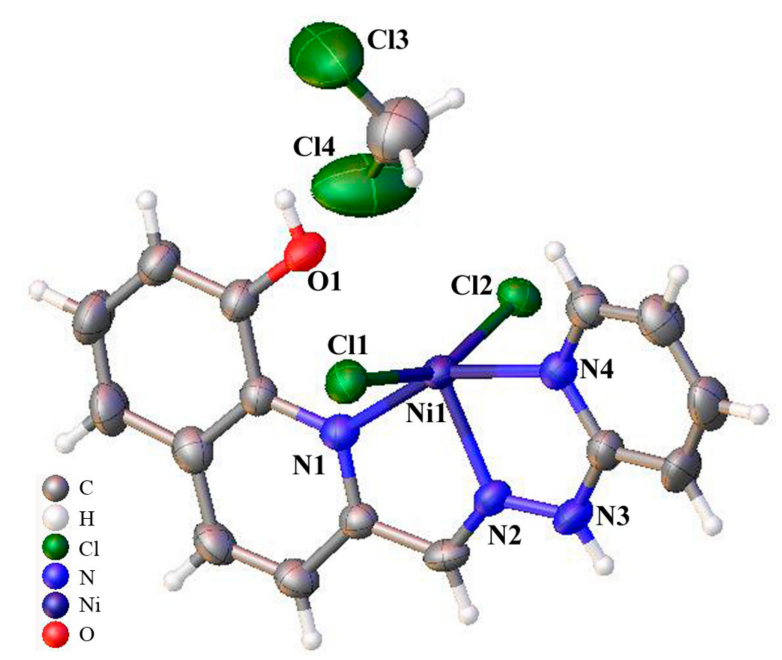

Figure 2. The crystal structure of complex 2. 


\subsection{Stability in Solution}

Ligand L, complexes $\mathbf{1}$ and $\mathbf{2}$ were tested for their stabilities in both dimethyl sulfoxide (DMSO) and Tris- $\mathrm{HCl}$ buffer solution (TBS) (TBS solution with $\mathrm{pH}$ at 7.35, containing $1 \%$ DMSO) by means of UV-Vis spectroscopy. The time-dependent (in the time course of $0,12,24,36$ and $48 \mathrm{~h}$ ) UV-Vis spectra of each complex dissolved in TBS solution are shown in Figure S1. There were no obvious changes in the spectral characteristics and the peak absorptions for ligand L, complexes $\mathbf{1}$ and $\mathbf{2}$ over the time course. In addition, the stabilities of $\mathrm{L}$, complexes $\mathbf{1}$ and $\mathbf{2}$ were monitored by high performance liquid chromatography (HPLC) detected at $245 \mathrm{~nm}$, and no significant change was observed for these three compounds in TBS at 0, 24, and $48 \mathrm{~h}$ (Figure S2). Combining the ESI-MS data, the results suggested that complex $\mathbf{2}$ was stable in TBS solution, and complexes $\mathbf{1}$ was stable in TBS solution as mononuclear species because it was dissociated in water solution and Tris- $\mathrm{HCl}$ buffer (see the results of Figure S9).

\subsection{In Vitro Cytotoxicity}

The in vitro cytotoxicities of $\mathrm{L}$, complexes 1 and 2 were evaluated by MTT assay in seven human tumor cell lines Hep-G2, SK-OV-3, MGC80-3, HeLa, T-24, BEL-7402, and NCI-H460 and one normal liver cell line HL-7702. Each compound was prepared as $2.0 \mathrm{mM}$ DMSO stock solution before it was diluted in PBS buffer to $20 \mu \mathrm{M}$ aqueous solutions (containing 2.5\% DMSO). These $20 \mu \mathrm{M}$ aqueous solutions were stable and no precipitate was formed.

The in vitro antitumor activities of complex 1 were further evaluated by determining the corresponding $\mathrm{IC}_{50}$ values. As shown in Table 1 , the $\mathrm{IC}_{50}$ values of complex $\mathbf{1}$ against SK-OV-3, MGC80-3 and HeLa were $3.69 \pm 0.16,2.60 \pm 0.17$, and $3.62 \pm 0.12 \mu \mathrm{M}$, respectively, which were approximately $11.6,15.6$, and 16.2 fold increases compared with that of the free L. In addition, complex 1 exhibited stronger cytotoxicities than cisplatin towards the SK-OV-3, MGC80-3, and HeLa tumor cells. In summary, complex 1 exhibited a lower $\mathrm{IC}_{50}$ value for MGC80-3 cells than other cells and higher cytotoxicity than complex 2 . Thus, complex 1 was chosen to study the underlying cellular and molecular mechanisms of its cytotoxicity. (As a support material, Inhibitory rates (\%) of compounds were shown in Table S4)

Table 1. The $\mathrm{IC}_{50}{ }^{\mathrm{a}}(\mu \mathrm{M})$ values of $\mathrm{L}$, complexes 1 and 2 to the selected tumor cells for $48 \mathrm{~h}$.

\begin{tabular}{|c|c|c|c|c|c|c|c|c|}
\hline Compounds & Hep-G2 & SK-OV-3 & MGC80-3 & HeLa & $\mathrm{T}-24$ & BEL-7402 & NCI-H460 & HL-7702 \\
\hline L & $58.40 \pm 0.69$ & $42.94 \pm 2.64$ & $40.93 \pm 0.94$ & $58.73 \pm 1.29$ & $85.93 \pm 15.11$ & $47.85 \pm 0.37$ & $36.93 \pm 3.93$ & $48.63 \pm 0.34$ \\
\hline 1 & $4.51 \pm 0.38$ & $3.69 \pm 0.16$ & $2.60 \pm 0.17$ & $3.62 \pm 0.12$ & $4.41 \pm 0.06$ & $5.92 \pm 0.01$ & $5.01 \pm 0.16$ & $12.78 \pm 0.55$ \\
\hline 2 & $>100$ & $39.77 \pm 2.15$ & $38.99 \pm 2.42$ & $27.13 \pm 6.51$ & $18.97 \pm 3.47$ & $51.68 \pm 0.66$ & $36.31 \pm 3.75$ & $31.73 \pm 2.11$ \\
\hline Cisplatin $\mathrm{b}$ & $9.55 \pm 0.46$ & $16.32 \pm 1.37$ & $12.37 \pm 1.53$ & $9.45 \pm 2.05$ & $28.15 \pm 1.67$ & $19.4 \pm 0.58$ & $9.59 \pm 0.48$ & $15.87 \pm 0.36$ \\
\hline
\end{tabular}

\subsection{Cell Cycle Analysis and Expressions of the Related Proteins}

The $\mathrm{IC}_{50}$ value of complex 1 towards the MGC80-3 cells was in the low micromolar range. To determine the cell cycle phase of growth arrest by complex 1, the DNA content of cells was estimated by flow cytometry after the cells were stained with propidiumiodide (PI). As shown in Figure 3, complex 1 caused a dose-dependent accumulation of MGC80-3 cells in the S phase, whereas most of the control cells were in the G1 and G2/M phase of the cell cycle. Additionally, the cell population of S phase increased from $20.77 \%$ in the control to $60.18 \%$ in the MGC $80-3$ cells treated with $8 \mu \mathrm{M}$ of complex 1 for $24 \mathrm{~h}$. After incubating the cells with complex $\mathbf{1}(8 \mu \mathrm{M})$ for $24 \mathrm{~h}$, the cell population of the G2/M phase was decreased to $0.00 \%$. These results indicated that the MGC $80-3$ cells were mainly blocked in the $S$ phase.

The protein expression levels of ATR, ATM, Cdc25 A, Cyclin B, Cyclin A, CDK2, p27, p21, and p53 protein in MGC80-3 cells after treated with complex $1(2.0,2.6,5.2$, and $8.0 \mu \mathrm{M})$ for $24 \mathrm{~h}$ were determined by Western blot and the results are shown in Figure 4, which demonstrated that complex 1 
caused a dose-dependent inhibition on the protein expression levels of Cdc25 A, Cyclin B, Cyclin A, and CDK2, and decreased levels of p27, p21, and p53 proteins.
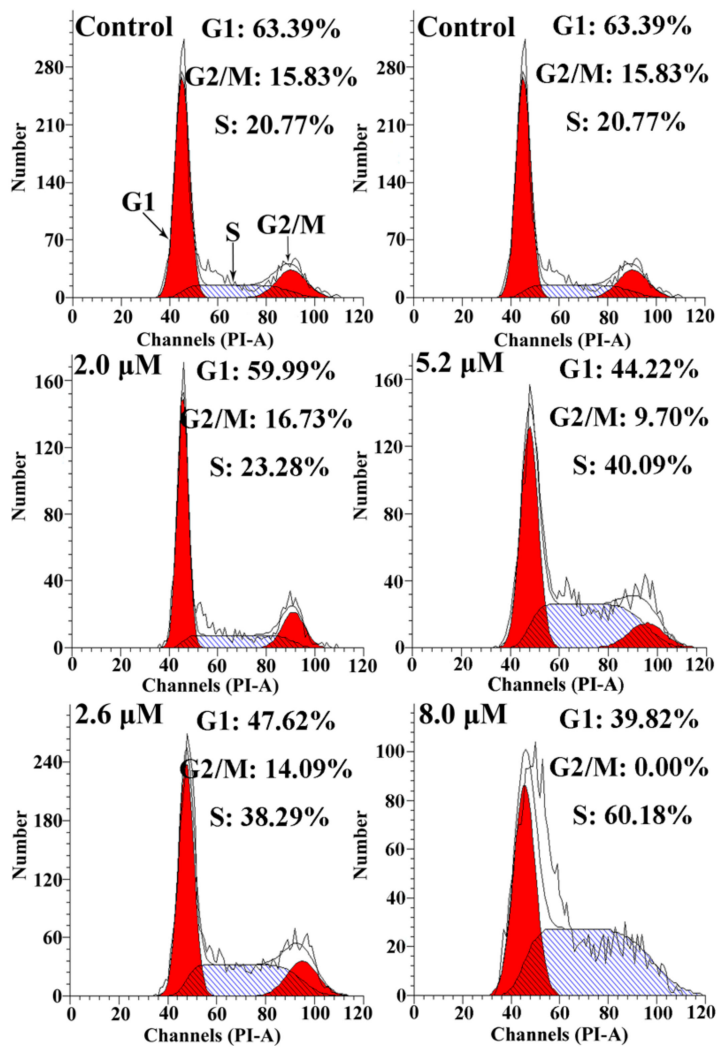

Figure 3. The cell cycle analysis by flow cytometry of MGC80-3 cells treated with complex 1 (2.0, 2.6, 5.2 , and $8.0 \mu \mathrm{M})$ for $24 \mathrm{~h}$.
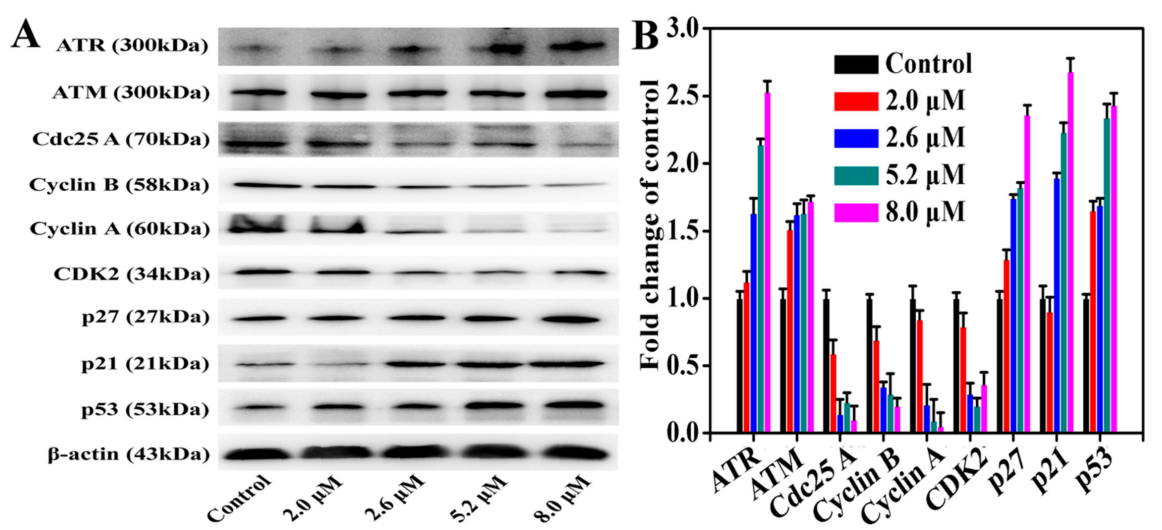

Figure 4. The expressions of ATR, ATM, Cdc25 A, Cyclin B, Cyclin A, CDK2, p27, p21, and p53 protein in MGC80-3 cells after treated with complex $\mathbf{1}(2.0,2.6,5.2$, and $8.0 \mu \mathrm{M})$ for $24 \mathrm{~h}$ were analyzed by Western blot. (A) The same blots were stripped and re-probed with a $\beta$-actin antibody to show equal protein loading; (B) The whole-cell extracts were prepared and analyzed by Western blot analysis using antibodies against cell cycle protein regulator proteins. The same blots were stripped and re-probed with the $\beta$-actin antibody to show equal protein loading. Western blotting bands from three independent measurements were quantified with Image J in (A). 


\subsection{Apoptosis Assay}

Apoptosis assay can provide important information for the preliminary investigation of the mode of action [55-57]. To determine whether the death of MGC80-3 cells induced by complex 1 resulted from apoptosis or necrosis, common biochemical markers of apoptosis were monitored, including mitochondrial membrane depolarization, chromatin condensation, and phosphatidylserine exposure. The cells subjected to annexin V-FITC and PI staining were classified as necrotic cells (Q1; annexin $\mathrm{V}-/ \mathrm{PI}+)$, early apoptotic cells $(\mathrm{Q} 2$; annexin $\mathrm{V}+/ \mathrm{PI}-)$, late apoptotic cells (Q3; annexin $\mathrm{V}+/ \mathrm{PI}+)$, and intact cells (Q4; annexin $\mathrm{V}-/ \mathrm{PI}-$ ). The assay showed (Figure 5) that complex $1(1.5,2.0,2.6$, and $3.6 \mu \mathrm{M})$ induced the apoptotic death of MGC80-3 cells as measured by annexin V staining and flow cytometry. After treatment with complex $\mathbf{1}$ for $24 \mathrm{~h}$, the populations of apoptotic cells (Q2+Q3) changed from $7.08 \%$ to $27.39 \%$ with the increase of complex $\mathbf{1}$ concentration, but the population of apoptotic cells $(\mathrm{Q} 2+\mathrm{Q} 3)$ of control was only $1.70 \%$. The significantly increased percentages of apoptotic cells confirmed that complex 1 effectively induced MGC80-3 cell apoptosis in a dose-dependent manner, which was consistent with the results of the MTT assay.

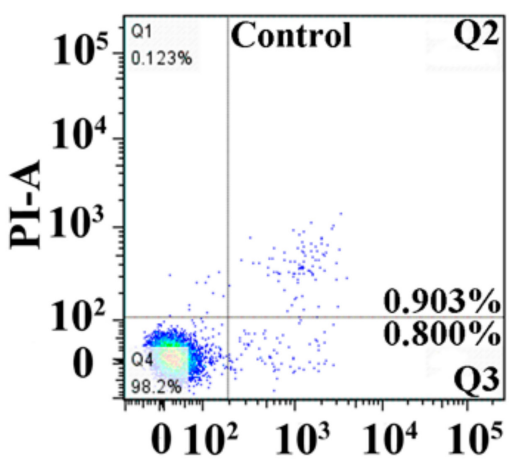

Annexin V-A

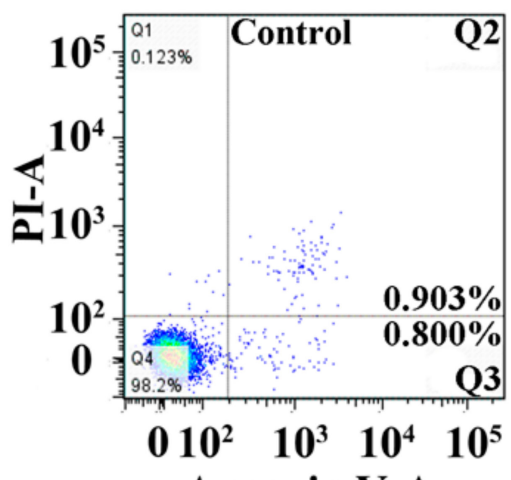

Annexin V-A

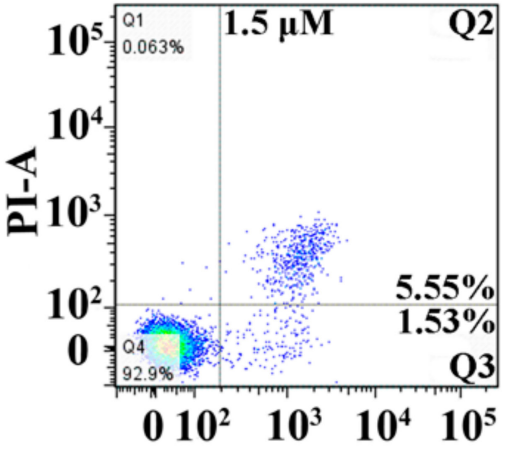

Annexin V-A

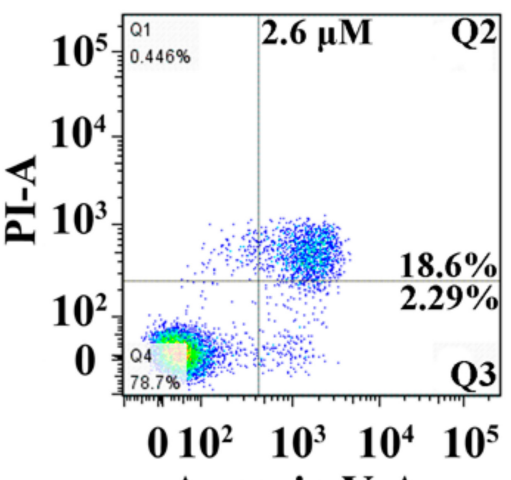

Annexin V-A

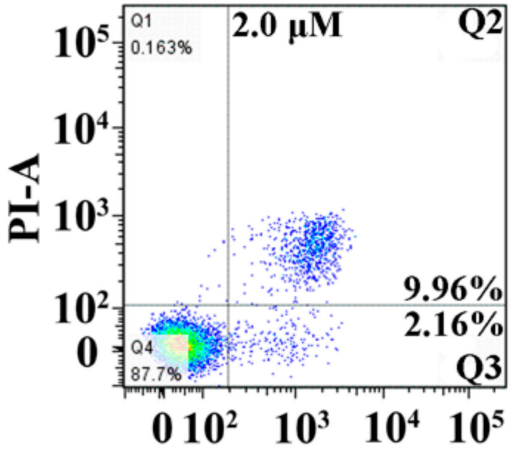

Annexin V-A

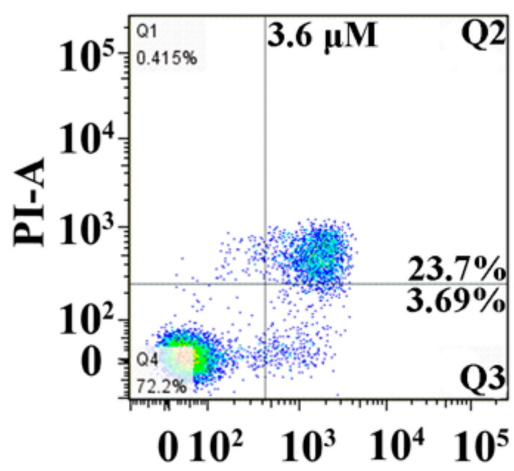

Annexin V-A

Figure 5. The Annexin V/propidium iodide assay and flow cytometry assay of MGC80-3 cells treated with $\mathrm{Cu}(\mathrm{II})$ complex $\mathbf{1}(1.5,2.0,2.6$ and $3.6 \mu \mathrm{M})$.

\subsection{Loss of Mitochondrial Membrane Potential in MGC80-3 Cells}

Growing evidence has shown that mitochondria play a key role in the progression of apoptosis, and the loss of mitochondrial membrane potential $(\Delta \psi)$ is involved in apoptotic cell death due to the cytotoxicity of the antitumor compounds [58-60]. The changes in $\Delta \psi$ induced by complex 1 are shown in Figures 6 and 7. JC-1 staining was used as a fluorescent probe [58]. After the MGC80-3 cells were treated with complex 1 for $24 \mathrm{~h}$, the $\Delta \psi$ decreased significantly with the increase of dose (from 2.0 to $8.0 \mu \mathrm{M}$ ) of complex $\mathbf{1}$, suggesting that the induction of apoptosis by complex $\mathbf{1}$ was associated with the intrinsic (mitochondrial) pathway. 

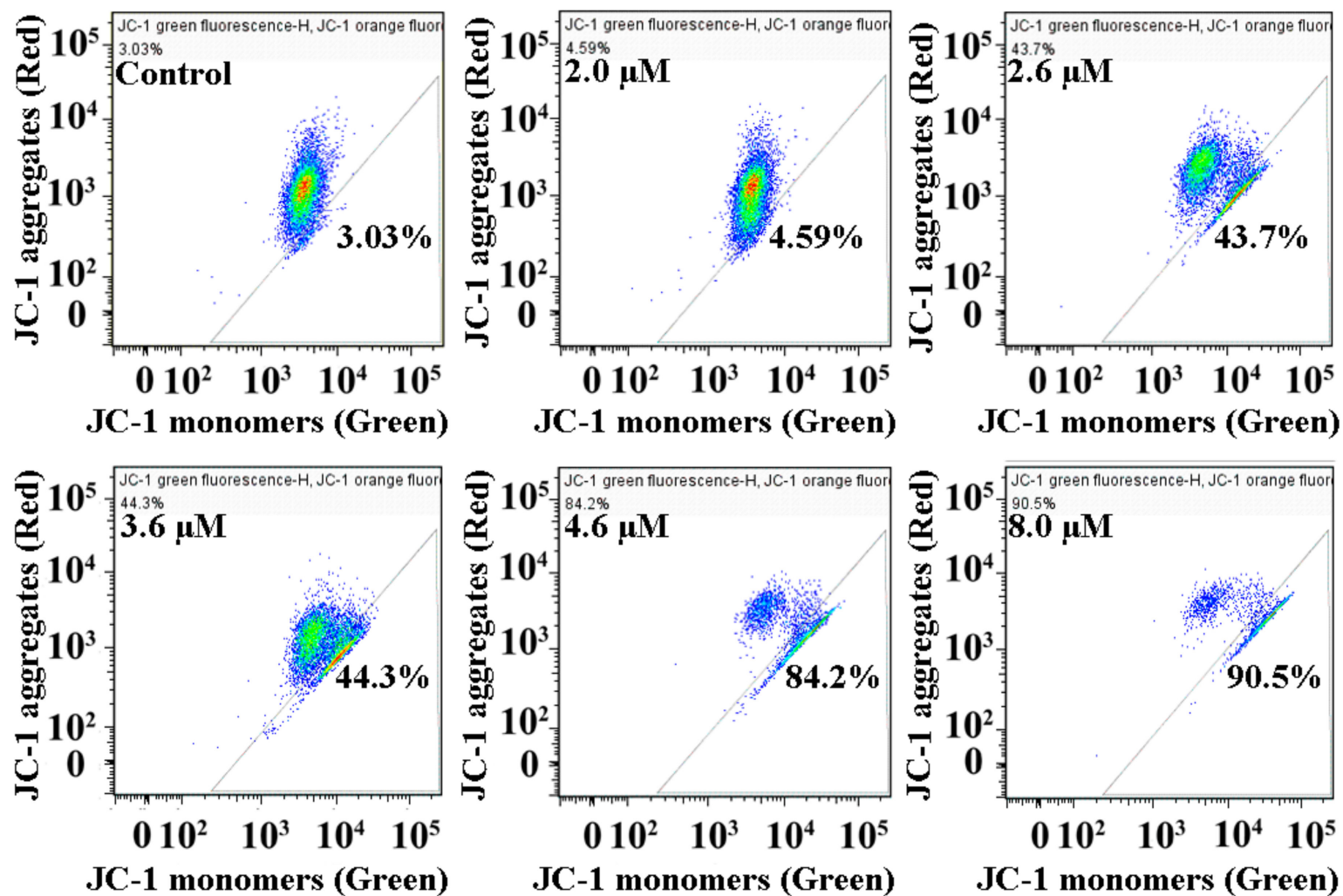

Figure 6. The collapse of mitochondrial membrane potential in MGC80-3 cells treated with $\mathrm{Cu}$ (II) complex 1 for $24 \mathrm{~h}$, as determined by JC-1 staining.

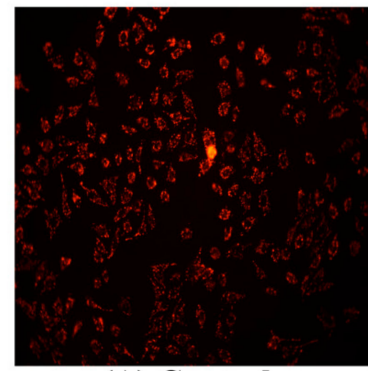

(A) Control

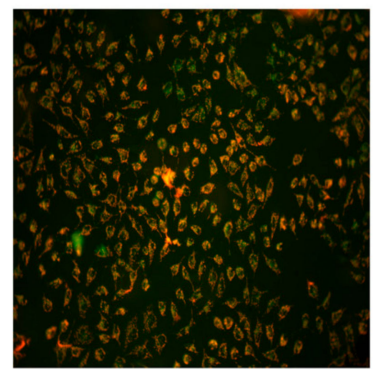

(B) $2.0 \mu \mathrm{M}$

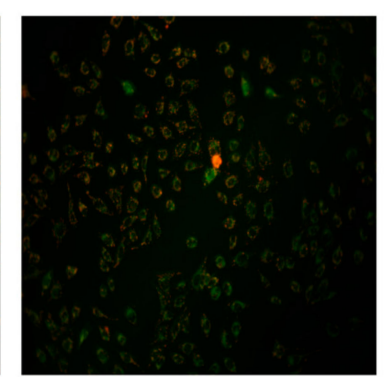

(C) $2.6 \mu \mathrm{M}$

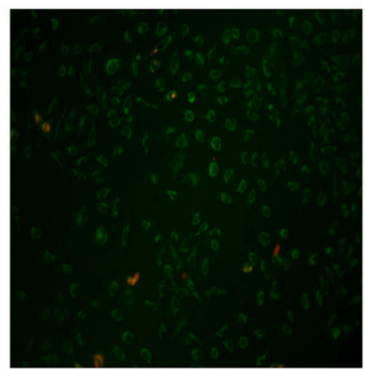

(D) $3.6 \mu \mathrm{M}$

Figure 7. The loss of $\Delta \psi$ in MGC80-3 cells treated with complex $1(2.0,2.6$ and $3.6 \mu \mathrm{M})$ for $24 \mathrm{~h}$, and the cells were examined under a fluorescence microscope (Nikon Te2000, 200×) after being stained with JC-1.

\subsection{Intracellular $\mathrm{Ca}^{2+}$}

The mitochondrial membrane potential $\Delta \psi$ can alter the intracellular $\mathrm{Ca}^{2+}$ level, which has been recognized as a factor in cell death, apoptosis, and injury mediated by various pathways [61,62]. We examined the effects of complex 1 on the mobilization of intracellular $\mathrm{Ca}^{2+}$ in MGC80-3 cells. As shown in Figure 8, the level of intracellular free $\mathrm{Ca}^{2+}$ in MGC80-3 cells was lower than that of the control group, but it increased steadily in a dose-dependent manner $(2.0,2.3$, and $3.6 \mu \mathrm{M}$ of complex 1$)$. Therefore, the changes of the intracellular $\mathrm{Ca}^{2+}$ level could be involved in the induction of apoptosis by complex 1 in MGC80-3 cells. 


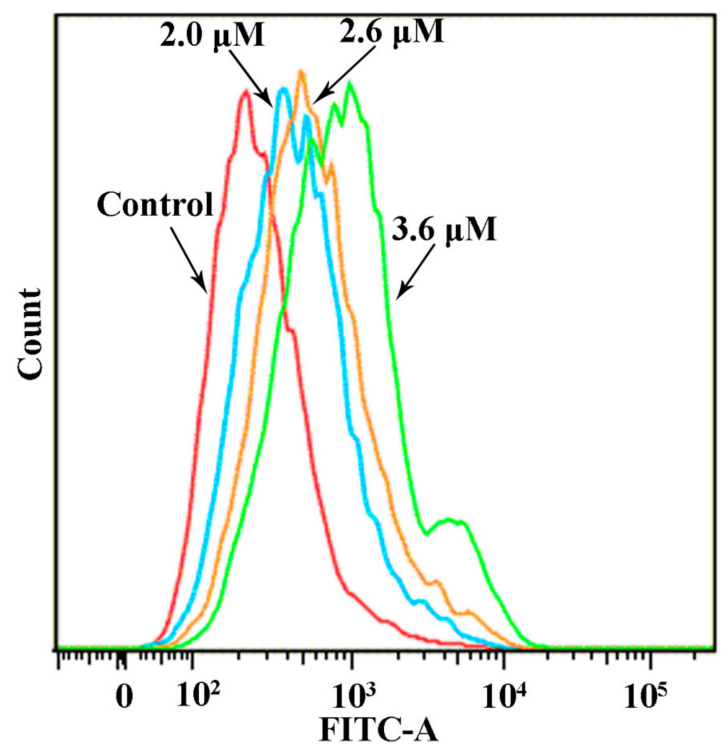

Figure 8. The effect of complex $1(2.0,2.6$, and $3.6 \mu \mathrm{M})$ on the intracellular free $\mathrm{Ca}^{2+}$ level in MGC80-3 cells for $24 \mathrm{~h}$.

\subsection{Reactive Oxygen Species (ROS) Level}

The dysregulation of ROS generation could dramatically affect cancer cell structure and result in cell damage, and consequently cell death and apoptosis [63,64]. To determine whether ROS generation is involved in the apoptosis or death of MGC80-3 cells induced by complex 1, the ROS level was measured by a fluorescent marker after the MGC80-3 cells were treated with complex 1 (2.0, 2.6, and $3.6 \mu \mathrm{M}$ ) for $24 \mathrm{~h}$. As shown in Figures 9 and 10, the levels of ROS in MGC80-3 cells were higher than that in the control after treatment, and the levels of ROS increased in a dose-dependent manner (from 2.0 to $3.6 \mu \mathrm{M}$ of complex 1). The results confirmed that complex 1 stimulated ROS-induced apoptosis in MGC80-3 cells.

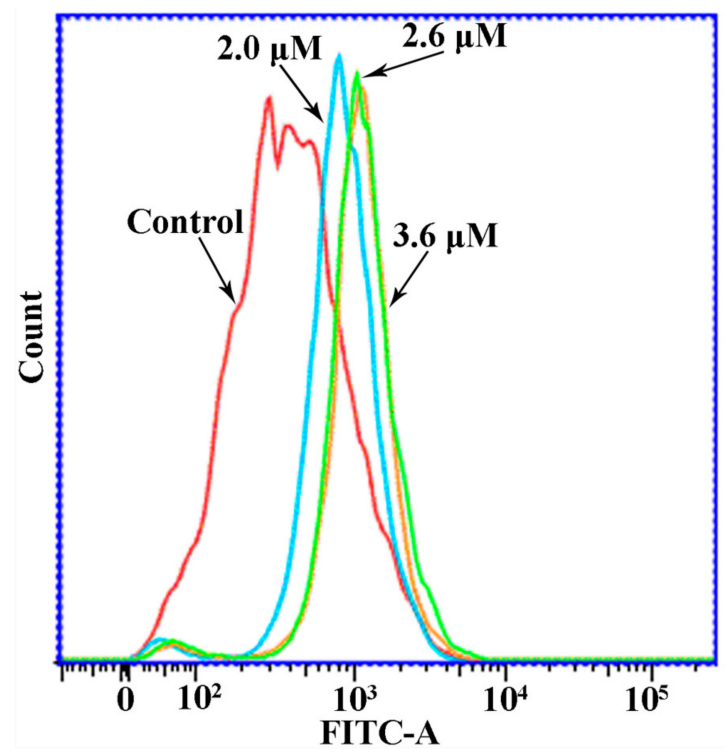

Figure 9. The ROS generation assay by flow cytometry analysis of MGC80-3 cells treated with complex $\mathbf{1}(2.0,2.6$, and $3.6 \mu \mathrm{M})$. Results are expressed as relative fluorescent intensities (from left to right). 


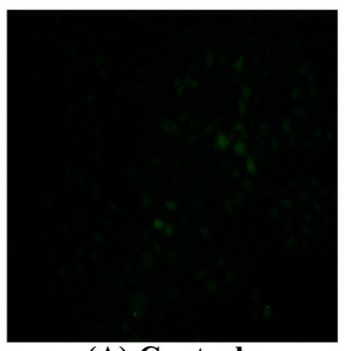

(A) Control

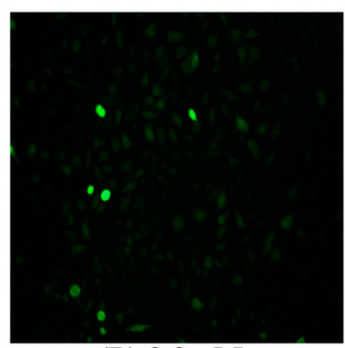

(B) $2.0 \mu \mathrm{M}$

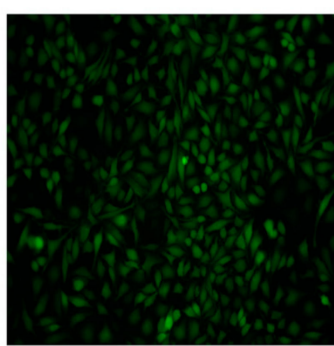

(C) $2.6 \mu \mathrm{M}$

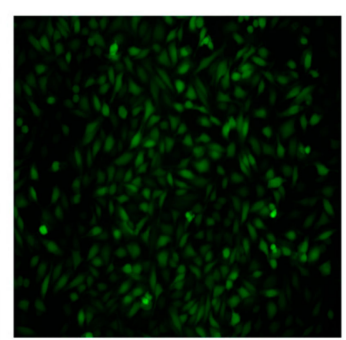

(D) $3.6 \mu \mathrm{M}$

Figure 10. The ROS generation assay of MGC80-3 cells treated with complex $1(2.0,2.6$, and $3.6 \mu \mathrm{M})$, and the cells were examined under a fluorescence microscope (Nikon Te2000, 200×).

\subsection{Western Blot Assay}

To further investigate the mechanism of action of complex 1, the cytochrome C (Cyt C), bcl-2, bax, and apaf-1 proteins in the mitochondria-related apoptotic pathway were assayed by Western blot [65]. Figure 11 shows that the levels of bax, Cyt C, and apaf- 1 proteins increased significantly and the level of bcl-2 protein decreased significantly in the MGC80-3 cells after treatment with complex 1 $(1.5,2.0,2.6$, and $3.6 \mu \mathrm{M})$ for $24 \mathrm{~h}$. Additionally, the levels of bax, Cyt C, and apaf-1 proteins increased in a dose-dependent manner. These results further demonstrated that complex $\mathbf{1}$ may be involved in mitochondria-related apoptosis [65].

A

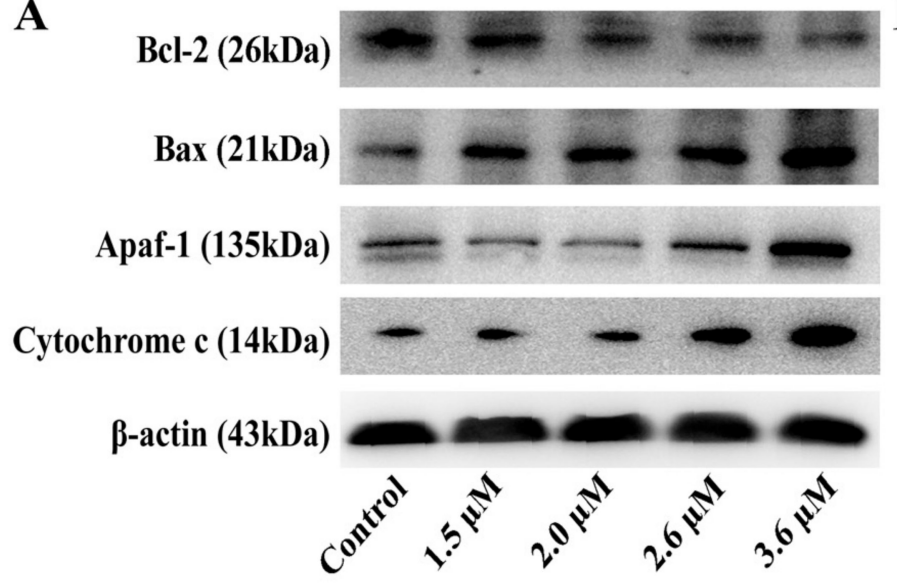

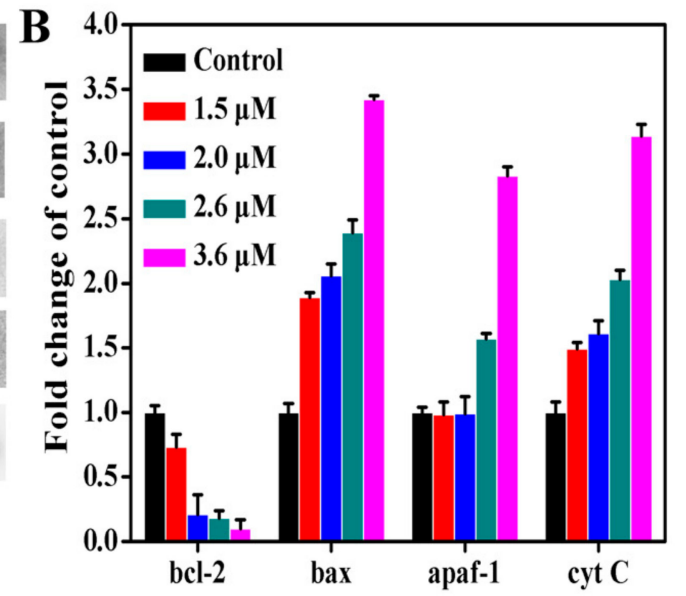

Figure 11. The western blot assay of apoptosis-related protein levels in Hep-G2 cells treated with complex $1(1.5,2.0,2.6$, and $3.6 \mu \mathrm{M})$ for $24 \mathrm{~h}$. (A) Western blot was used to determine the expression levels of bax, cytochrome c, apaf-1, and bcl-2 in MGC80-3 cells treated with complex 1 (1.5, 2.0, 2.6, and $3.6 \mu \mathrm{M}$ ) for $24 \mathrm{~h}$; (B) Densitometric analysis of apoptotic-related proteins normalized to $\beta$-actin. The relative expression of each protein is represented by the density of the protein band/density of $\beta$-actin band.

\subsection{Assessment of Caspase-3/9/8 Activation}

To determine whether caspase-3/9 were involved in the induced apoptotic cell death, MGC80-3 cells were analyzed by flow cytometry after treatment with complex $1(1.5,2.0$, and $2.6 \mu \mathrm{M})$ for $24 \mathrm{~h}$. The results showing peaks of activated caspase-3 (FITC-DEVD-FMK probes), activated caspase-8 (FITC-IETD-FMK probes), and activated caspase-9 (FITC-LEHD-FMK probes) for the treated cells are shown in Figure 12. It is notable that the proportion of cells with activated caspase-3, caspase-9, and caspase-8 increased from $5.04 \%$ to $18.70 \%, 2.59 \%$ to $23.9 \%$, and $6.45 \%$ to $21.60 \%$, respectively. Therefore, complex 1 could induce cell apoptosis by triggering the caspase-3/9/8 activity in MGC80-3 cells [66-69]. 


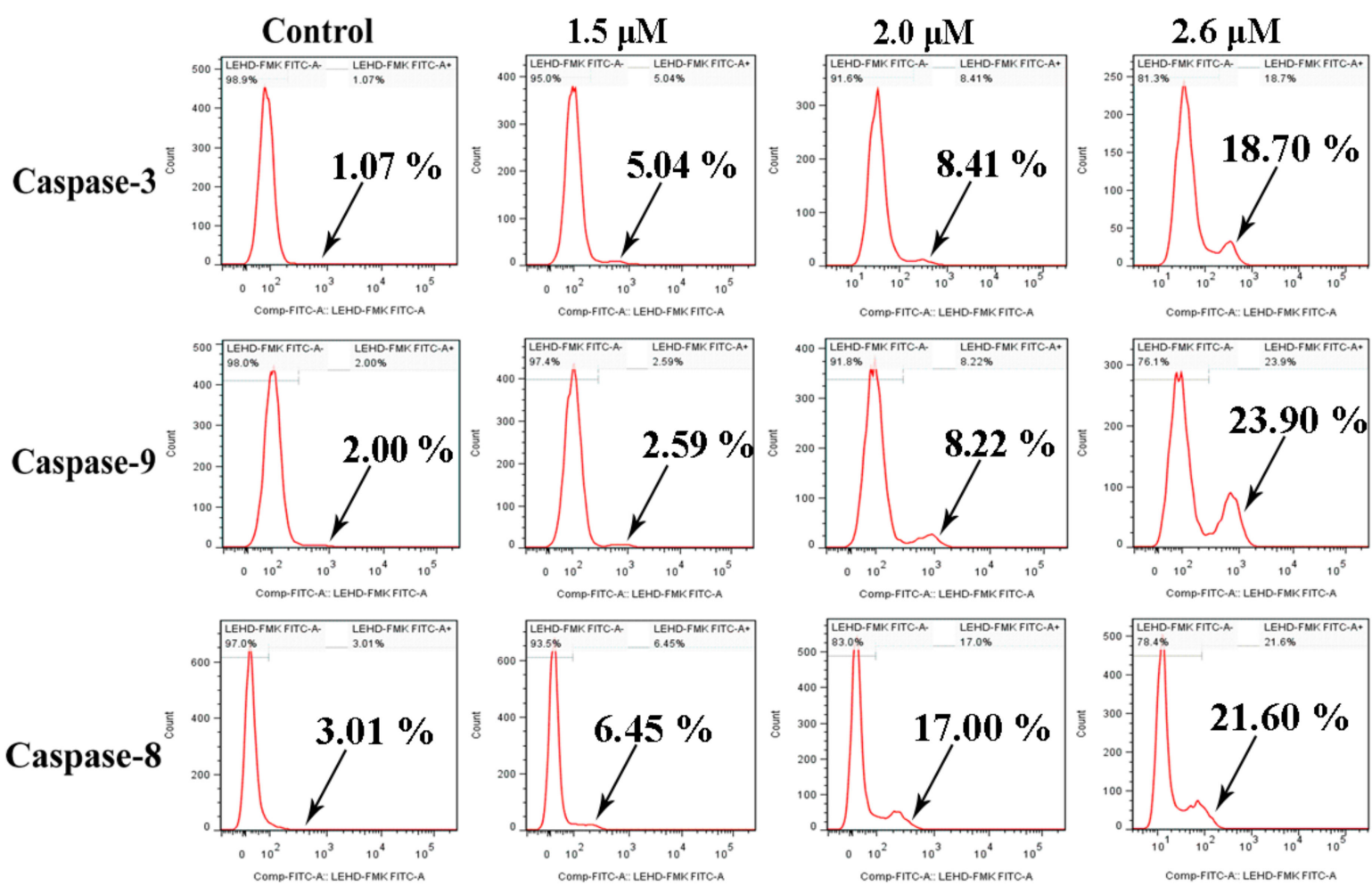

Figure 12. The activation of caspase-3, caspase- 8 , and caspase- 9 in MGC $80-3$ cells treated with complex $\mathbf{1}(1.5,2.0$, and $2.6 \mu \mathrm{M})$ for $24 \mathrm{~h}$.

Taken together, complex 1 induced apoptosis in MGC80-3 cells likely by disrupting mitochondrial function, which led to a significantly decreased level of bcl-2 protein and loss of $\Delta \psi$, as well as a significant increase in the levels of ROS, intracellular $\mathrm{Ca}^{2+}, \mathrm{Cyt} C$ protein, apaf- 1 protein, activated caspase-3, and activated caspase-9 in MGC80-3 cells.

\section{Materials and Methods}

\subsection{Materials}

All chemical reagents, including chloride salts and solvents, were of analytical grade. All materials were used as received without further purification unless specifically noted. All the synthetic complexes were dissolved in dimethyl sulfoxide (DMSO) for the preparation of stock solution at a concentration of $2.0 \mathrm{mM}$.

\subsection{Instrumentation}

Elemental analyses $(\mathrm{C}, \mathrm{H}, \mathrm{N})$ were carried out on a Perkin Elmer Series II CHNS/O 2400 elemental analyzer. NMR spectra were recorded on a Bruker AV-500 NMR spectrometer. Fluorescence measurements were performed on a Shimadzu RF-5301/PC spectrofluorophotometer. The region between 200 and $400 \mathrm{~nm}$ was scanned for each sample. UV-Vis spectra were recorded on a TU-1901 ultraviolet spectrophotometer.

\subsection{Synthesis}

\subsubsection{Synthesis of $\mathrm{L}$}

The 2-((2-(pyridin-2-yl)hydrazono)methyl)quinolin-8-ol (L) was obtained from the condensation reaction of 8-hydroxyquinoline-2-carbaldehyde with 2-hydrazinylpyridine in good yield (89.0\%) [44], as shown in Scheme 2. m.p. $238^{\circ} \mathrm{C} ;{ }^{1} \mathrm{H}-\mathrm{NMR}\left(500 \mathrm{MHz}\right.$, DMSO-d $\left.d_{6}\right) \delta 11.46(\mathrm{~s}, 1 \mathrm{H}, \mathrm{OH}), 9.72(\mathrm{~s}, 1 \mathrm{H}$, $\mathrm{NH}), 8.27(\mathrm{~d}, J=9.0 \mathrm{~Hz}, 2 \mathrm{H}), 8.18(\mathrm{~d}, J=4.0 \mathrm{~Hz}, 1 \mathrm{H}), 8.14(\mathrm{~d}, J=8.6 \mathrm{~Hz}, 1 \mathrm{H}), 7.74-7.68(\mathrm{~m}, 1 \mathrm{H})$, 
7.42-7.36 (m, 3H), 7.09 (dd, $J=7.2,1.5 \mathrm{~Hz}, 1 \mathrm{H}), 6.85(\mathrm{dd}, J=6.9,5.1 \mathrm{~Hz}, 1 \mathrm{H}) ;{ }^{13} \mathrm{C}-\mathrm{NMR}(125 \mathrm{MHz}$, DMSO- $\left.d_{6}\right) \delta 157.10,153.61,153.16,148.32,139.65,138.60,138.52,136.57,128.71,127.87,118.22,117.91$, 116.27, 112.41, 107.19; HRMS(EI): Calcd for $\mathrm{C}_{15} \mathrm{H}_{13} \mathrm{~N}_{4} \mathrm{O}[\mathrm{L}+\mathrm{H}]^{+}, m / z$ 265.1089, found $m / z$ 265.1086. IR $\left(\mathrm{cm}^{-1}\right): v_{\mathrm{NH}}=3049 \mathrm{~cm}^{-1} ; v_{\mathrm{C}=\mathrm{N}}=1580 \mathrm{~cm}^{-1}$. (The ${ }^{1} \mathrm{H}-\mathrm{NMR},{ }^{13} \mathrm{C}-\mathrm{NMR}$ and MS were shown in Figures S6-S8)

\subsubsection{Synthesis of Complex 1}

The mixture of ligand $\mathrm{L}(0.26 \mathrm{~g}, 1.0 \mathrm{mmol})$ and $\mathrm{CuCl}_{2} \cdot 2 \mathrm{H}_{2} \mathrm{O}(0.17 \mathrm{~g}, 1.0 \mathrm{mmol})$ in $20 \mathrm{~mL}$ methanol was maintained at reflux $\left(70{ }^{\circ} \mathrm{C}\right)$ for $6 \mathrm{~h}$ to afford complex 1 as black crystals in $70 \%$ yield. The black crystals of complex 1 suitable for X-ray diffraction analysis were subsequently harvested. ESI-MS $m / z$ : 427.0361 $[\mathrm{Cu}(\mathrm{L}) \mathrm{Cl}+\mathrm{H}+2 \mathrm{MeOH}]^{+}$. Anal. Calcd for $\mathrm{C}_{30} \mathrm{H}_{24} \mathrm{Cl}_{4} \mathrm{Cu}_{2} \mathrm{~N}_{8} \mathrm{O}_{2}: \mathrm{C}, 45.18 ; \mathrm{H}, 3.03 ; \mathrm{N}, 14.05 ; \mathrm{O}$, 4.01; Found: $\mathrm{C}, 45.16 ; \mathrm{H}, 3.02 ; \mathrm{N}, 15.07$. IR $\left(\mathrm{cm}^{-1}\right): v_{\mathrm{NH}}=3101 \mathrm{~cm}^{-1} ; v_{\mathrm{C}=\mathrm{N}}=1636 \mathrm{~cm}^{-1}$. (The MS was shown in Figure S9)

\subsubsection{Synthesis of Complex 2}

By means of the similar procedure, complex 2 was obtained from $\mathrm{NiCl}_{2} \cdot 6 \mathrm{H}_{2} \mathrm{O}$ as black crystals in $75 \%$ yield. The black crystals of complex 2 suitable for $\mathrm{X}$-ray diffraction analysis were subsequently harvested. ESI-MS $m / z: 321.0281[\mathrm{Ni}(\mathrm{L})+\mathrm{H}]^{+}$. Anal. calcd for $\mathrm{C}_{16} \mathrm{H}_{14} \mathrm{Cl}_{4} \mathrm{~N}_{4} \mathrm{NiO}: \mathrm{C}, 40.13 ; \mathrm{H}, 2.95 ; \mathrm{N}$, 11.70; Found: $\mathrm{C}, 40.14 ; \mathrm{H}, 2.94 ; \mathrm{N}, 11.69$. IR $\left(\mathrm{cm}^{-1}\right): v_{\mathrm{NH}}=3060 \mathrm{~cm}^{-1} ; v_{\mathrm{C}=\mathrm{N}}=1615 \mathrm{~cm}^{-1}$. (The MS was shown in Figure S10)

\subsection{X-ray Crystallography}

Complexes $1(0.31 \times 0.22 \times 0.10 \mathrm{~mm})$ and $2(0.34 \times 0.18 \times 0.17 \mathrm{~mm})$ were measured on an Agilent SuperNova CCD area detector (Rigaku Corporation, Tokyo, Japan) equipped with a graphite-monochromatic Mo-K $\alpha$ radiation source $(\lambda=0.71073 \AA$ ) at room temperature 293(2) K. All non-hydrogen atoms' positions and anisotropic thermal parameters were refined on F2 by full-matrix least-squares techniques with the SHELX-97 program package [70]. The hydrogen atoms were added theoretically, riding on the concerned atoms. The semi-empirical methods from equivalents were used to correct absorption. The crystallographic data and refinement details of the structures are summarized in Tables S1-S3 (Supporting Information).

\subsection{In Vitro Cytotoxicity}

Seven tumor cells Hep-G2, SK-OV-3, MGC80-3, HeLa, T-24, BEL7402, and NCI-H460 and one normal liver cell HL-7702 were obtained from the Shanghai Cell Bank in the Chinese Academy of Sciences. Cells were grown in triplicate in 96-well plates (Gibco, Carlsbad, CA, USA) and incubated at $37{ }^{\circ} \mathrm{C}$ for $48 \mathrm{~h}$ in a humidified atmosphere containing $5 \% \mathrm{CO}_{2}$ and $95 \%$ air. To investigate the potential activity of $\mathrm{L}$ and complexes $\mathbf{1}$ and 2, cisplatin was employed as a reference metallodrug. Cytotoxicity assays were carried out in 96-well flat-bottomed microtite plates that were supplemented with culture medium and cells. Ligand L, complexes $\mathbf{1}$ and $\mathbf{2}$, and cisplatin were dissolved in the culture medium at various concentrations $(1.25,2.5,5.0,10.0$, and $20.0 \mu \mathrm{M})$ with $1 \%$ DMSO and the resulting solutions were subsequently added to a set of wells. The control wells contained supplemented medium with $1 \%$ DMSO. The microtitre plates were then incubated at $37{ }^{\circ} \mathrm{C}$ under a humidified atmosphere containing $5 \% \mathrm{CO}_{2}$ and $95 \%$ air for 2 days. Cytotoxicity screening was conducted through 3-(4,5-dimethylthiazol-2-yl)-2,5-diphenyltetrazolium bromide (MTT) assay. After each incubation period, the MTT solution $\left(10 \mathrm{~mL}, 5 \mathrm{mg} \cdot \mathrm{mL}^{-1}\right)$ was added into each well and the cultures were incubated at $37{ }^{\circ} \mathrm{C}$ in a humidified atmosphere containing $5 \% \mathrm{CO}_{2}$ and $95 \%$ air for a further $48 \mathrm{~h}$. After the removal of the supernatant, DMSO $(150 \mathrm{~mL})$ was added to dissolve the formazan crystals.

The absorbance at 490 and $630 \mathrm{~nm}$ was read on a plate reader. Relative to the negative control, cytotoxicity was estimated based on the percentage cell survival in a dose-dependent manner. The final 
$\mathrm{IC}_{50}$ values were calculated by the Bliss method $(n=5)$. All tests were repeated in at least three independent experiments.

\subsection{Cell Cycle Arrest}

The MGC80-3 cells were maintained in Dulbecco's modified Eagle's medium with $10.0 \%$ fetal calf serum under $5 \% \mathrm{CO}_{2}$ at $37^{\circ} \mathrm{C}$. The cells were harvested by trypsinization, rinsed with PBS, and centrifuged at $3000 \times g$ for $10 \mathrm{~min}$. The pellet (105-106 cells) was suspended in PBS (1.0 mL) and kept on ice for $5 \mathrm{~min}$. The cell suspension was then fixed by the dropwise addition of $9 \mathrm{~mL}$ precooled $\left(4^{\circ} \mathrm{C}\right) 100 \%$ ethanol with vigorous shaking, and the fixed samples were kept at $4{ }^{\circ} \mathrm{C}$ until use. For staining, the cells were centrifuged, resuspended in PBS, digested with $150 \mathrm{~mL}$ RNase A $\left(250 \mu \mathrm{g} \cdot \mathrm{mL}^{-1}\right)$, treated with $150 \mathrm{~mL}$ PI $(0.15 \mathrm{mM})$, and then incubated for $30 \mathrm{~min}$ at $4{ }^{\circ} \mathrm{C}$. PI-positive cells were counted with a fluorescence-activated cell sorter (FACS). The population of cells in each cell cycle was determined by the Cell Modi FIT software (Becton Dickinson, version 1.0, San Jose, CA, USA).

\subsection{Other Experimental Methods}

The supporting information provides the detailed procedures of other experimental methods, including the measurement of mitochondrial membrane potential (by JC-1 staining), ROS generation, intracellular free $\mathrm{Ca}^{2+}$, Western blot, and caspase-3/9 activity. The procedures were similar to those given in the previous work of Chen et al. [71].

\subsection{Statistics}

Data processing included the Student's $t$-test with $p \leq 0.05$ taken as significance level, using SPSS 13.0 (IBM, Armonk, NY, USA).

\section{Conclusions}

Two transition metal complexes with 2-((2-(pyridin-2-yl) hydrazono) methyl)quinolin-8-ol (L), $\left[\mathrm{Cu}(\mathrm{L}) \mathrm{Cl}_{2}\right]_{2}(\mathbf{1})$ and $\left[\mathrm{Ni}(\mathrm{L}) \mathrm{Cl}_{2}\right] \cdot \mathrm{CH}_{2} \mathrm{Cl}_{2}(2)$, were synthesized and fully characterized. In vitro antitumor screening revealed that complex $\mathbf{1}$ exhibited higher inhibitory activities than cisplatin against SK-OV-3, MGC80-3, and HeLa cells. In addition, complex 1 caused MGC80-3 cell arrest in the S phase, which led to the significant down-regulation of the related proteins. Complex 1 can down-regulate the expression of the bcl-2 protein and upregulate the levels of the bax, Cyt C, and apaf-1 proteins in MGC80-3 cells. We found that complex $\mathbf{1}$ induced MGC80-3 cell apoptosis via a mitochondrial dysfunction pathway, which was mediated by $\Delta \psi$, ROS, and intracellular $\mathrm{Ca}^{2+}$. Moreover, complex 1 could induce cell apoptosis by triggering the caspase-3/9/8 activity in MGC80-3 cells. Therefore, complex 1 is a potent anticancer drug candidate.

Supplementary Materials: Can be found at http://www.mdpi.com/1422-0067/19/7/1874/s1, Full cif depositions (excluding structure factors) lodged with the Cambridge Crystallographic Data Centre (CCDC 1848527 (for complexes 1), 1848516 (for complexes 2)) contain the supplementary crystallographic data for this paper. These data can be obtained free of charge from The Cambridge Crystallographic Data Centre via www.ccdc.cam.ac.uk/data_request/cif.

Author Contributions: Q.-Y.Y., Q.-Q.C., Q.-P.Q., C.-X.D., H.L., Z.-F.C. conceived, designed the experiments, performed the experiments, analyzed the data, contributed reagents/materials/analysis tools, wrote and approved the final manuscript.

Acknowledgments: This work was supported by the National Natural Science Foundation of China (Grants 81473102, 21431001), IRT_16R15, CMEMR2012-A22, Natural Science Foundation of Guangxi Province (Grant No. 2012GXNSFDA053005) and Innovation Project of Guangxi Graduate Education (Grant No. YCBZ2018033) as well as "BAGUI Scholar" program of Guangxi Province of China.

Conflicts of Interest: The authors declare no conflict of interest. 


\section{References}

1. Chaudhuri, A.R.; Callen, E.; Ding, X.; Gogola, E.; Duarte, A.A.; Lee, J.E.; Wong, N.; Lafarga, V.; Calvo, J.A.; Panzarino, N.J.; et al. Replication fork stability confers chemoresistance in BRCA-deficient cells. Nature 2016, 535, 382-387. [CrossRef] [PubMed]

2. Cheff, D.M.; Hall, M.D. A Drug of Such Damned Nature.1 Challenges and Opportunities in Translational Platinum Drug Research. J. Med. Chem. 2017, 60, 4517-4532. [CrossRef] [PubMed]

3. Li, Y.; Li, A.; Wu, J.; He, Y.; Yu, H.; Chai, R.; Li, H. MiR-182-5p protects inner ear hair cells from cisplatin-induced apoptosis by inhibiting FOXO3a. Cell Death Dis. 2016, 7, e2362. [CrossRef] [PubMed]

4. Li, X.; Fang, C.; Zong, Z.; Cui, L.; Bi, C.; Fan, Y. Synthesis, characterization and anticancer activity of two ternary copper(II) Schiff base complexes. Inorg. Chim. Acta 2015, 432, 198-207. [CrossRef]

5. Saleem, K.; Wani, W.A.; Haque, A.; Lone, M.N.; Hsieh, M.F.; Jairajpuri, M.A.; Ali, I. Synthesis, DNA binding, hemolysis assays and anticancer studies of copper(II), nickel(II) and iron(III) complexes of a pyrazoline-based ligand. Future Med. Chem. 2013, 5, 135-146. [CrossRef] [PubMed]

6. Muralisankar, M.; Haribabu, J.; Bhuvanesh, N.S.P.; Karvembu, R.; Sreekanth, A. Synthesis, X-ray crystal structure, DNA/protein binding, DNA cleavage and cytotoxicity studies of $\mathrm{N}(4)$ substituted thiosemicarbazone based copper(II)/nickel(II) complexes. Inorg. Chim. Acta 2016, 449, 82-95. [CrossRef]

7. Wani, W.A.; Al-Othman, Z.; Ali, I.; Saleem, K.; Hsieh, M.F. Copper(II), nickel(II), and ruthenium(III) complexes of an oxopyrrolidine-based heterocyclic ligand as anticancer agents. J. Coord. Chem. 2014, 67, 2110-2130. [CrossRef]

8. Haleel, A.; Arthi, P.; Reddy, N.D.; Veenac, V.; Sakthivelc, N.; Arund, Y.; Perumald, P.T.; Rahiman, K. DNA binding, molecular docking and apoptotic inducing activity of nickel(II), copper(II) and zinc(II) complexes of pyridine-based tetrazolo[1,5-a] pyrimidine ligands. RSC Adv. 2014, 4, 60816-60830. [CrossRef]

9. Jin, Q.M.; Lu, Y.; Jin, J.L.; Guo, H.; Lin, G.W.; Wang, Y.; Lu, T. Synthesis, characterization, DNA binding ability and cytotoxicity of the novel platinum(II); copper(II), cobalt(II) and nickel(II) complexes with 3-(1H-benzo[d]imidazol-2-yl)- $\beta$-carboline. Inorg. Chim. Acta 2014, 421, 91-99. [CrossRef]

10. Rajalakshmi, S.; Kiran, M.S.; Nair, B.U. DNA condensation by copper(II) complexes and their anti-proliferative effect on cancerous and normal fibroblast cells. Eur. J. Med. Chem. 2014, 80, 393-406. [CrossRef] [PubMed]

11. Totta, X.; Papadopoulou, A.A.; Hatzidimitriou, A.G.; Papadopoulosb, A.; Psomas, G. Synthesis, structure and biological activity of nickel(II) complexes with mefenamato and nitrogen-donor ligands. J. Inorg. Biochem. 2015, 145, 79-93. [CrossRef] [PubMed]

12. Hsu, C.W.; Kuo, C.F.; Chuang, S.M.; Hou, M.H. Elucidation of the DNA-interacting properties and anticancer activity of a Ni(II)-coordinated mithramycin dimer complex. Biometals 2013, 26, 1-12. [CrossRef] [PubMed]

13. Tabrizi, L.; McArdle, P.; Erxleben, A.; Chiniforoshan, H. Nickel(II) and cobalt(II) complexes of lidocaine: Synthesis, structure and comparative invitro evaluations of biological perspectives. Eur. J. Med. Chem. 2015, 103, 516-529. [CrossRef] [PubMed]

14. Zhu, T.F.; Wang, Y.; Ding, W.J.; Xu, J.; Chen, R.H.; Xie, J.; Zhu, W.J.; Jia, L.; Ma, T.L. Anticancer Activity and DNA-Binding Investigations of the $\mathrm{Cu}(\mathrm{II})$ and $\mathrm{Ni}(\mathrm{II})$ Complexes with Coumarin Derivative. Chem. Biol. Drug Des. 2015, 85, 385-393. [CrossRef] [PubMed]

15. Alomar, K.; Landreau, A.; Allain, M.; Boueta, G.; Larcher, G. Synthesis, structure and antifungal activity of thiophene-2,3-dicarboxaldehyde bis(thiosemicarbazone) and nickel(II), copper(II) and cadmium(II) complexes: Unsymmetrical coordination mode of nickel complex. J. Inorg. Biochem. 2013, 126, 76-83. [CrossRef] [PubMed]

16. Ramírez-Macías, I.; Maldonado, C.R.; Marín, C.; Olmoa, F.; Gutiérrezsánchezc, R.; Rosalesa, M.J.; Quirósb, M.; Salasb, J.M. In vitro anti-leishmania evaluation of nickel complexes with a triazolopyrimidine derivative against Leishmania infantum and Leishmania braziliensis. J. Inorg. Biochem. 2012, 112, 1-9. [CrossRef] [PubMed]

17. Betanzos-Lara, S.; Gómez-Ruiz, C.; Barrón-Sosa, L.R.; Gracia-Mora, I.; Flores-Álamo, M.; Barba-Behrens, N. Cytotoxic copper(II), cobalt(II), zinc(II), and nickel(II) coordination compounds of clotrimazole. J. Inorg. Biochem. 2012, 114, 82-93. [CrossRef] [PubMed]

18. Turnaturi, R.; Oliveri, V.; Vecchio, G. Biotin-8-hydroxyquinoline conjugates and their metal complexes: Exploring the chemical properties and the antioxidant activity. Polyhedron 2016, 110, 254-260. [CrossRef]

19. Xu, H.; Chen, W.; Zhan, P.; Liu, X. 8-Hydroxyquinoline: A privileged structure with a broad-ranging pharmacological potential. MedChemComm 2015, 6, 61-74. [CrossRef] 
20. Prachayasittikul, V.; Prachayasittikul, S.; Ruchirawat, S.; Prachayasittikul, V. 8-Hydroxyquinolines: A review of their metal chelating properties and medicinal applications. Drug Des. Dev. Ther. 2013, 7, 1157-1178. [CrossRef] [PubMed]

21. Solomon, R.; Lee, H. Quinoline as a Privileged Scaffold in Cancer Drug Discovery. Curr. Med. Chem. 2011, 18, 1488-1508. [CrossRef] [PubMed]

22. Schimmer, A.D. Clioquinol-A Novel Copper-Dependent and Independent Proteasome Inhibitor. Cancer Drug Targets 2011, 11, 325-331. [CrossRef]

23. Matlack, K.E.; Tardiff, D.F.; Narayan, P.; Hamamichi, S.; Caldwell, K.A.; Caldwell, G.A.; Lindquist, S. Clioquinol promotes the degradation of metal-dependent amyloid- $\beta(\mathrm{A} \beta)$ oligomers to restore endocytosis and ameliorate A $\beta$ toxicity. Proc. Natl. Acad. Sci. USA 2014, 111, 4013-4018. [CrossRef] [PubMed]

24. Wang, L.; Esteban, G.; Ojima, M.; Bautista-Aguilera, O.M.; Inokuchi, T.; Moraleda, I.; Iriepa, I.; Samadi, A.; Youdim, M.B.; Romero, A.; et al. Donepezil + propargylamine + 8-hydroxyquinoline hybrids as new multifunctional metal-chelators; $\mathrm{ChE}$ and MAO inhibitors for the potential treatment of Alzheimer's disease. Eur. J. Med. Chem. 2014, 80, 543-561. [CrossRef] [PubMed]

25. Wu, M.Y.; Esteban, G.; Brogi, S.; Shionoya, M.; Wang, L.; Campiani, G.; Unzeta, M.; Inokuchi, T.; Butini, S.; Marco-Contelles, J. Donepezil-like multifunctional agents: Design, synthesis, molecular modeling and biological evaluation. Eur. J. Med. Chem. 2016, 121, 864-879. [CrossRef] [PubMed]

26. Jiang, H.; Taggart, J.E.; Zhang, X.; Benbrook, D.M.; Lind, S.E.; Ding, W.Q. Nitroxoline (8-hydroxy-5-nitroquinoline) is more a potent anti-cancer agent than clioquinol (5-chloro-7-iodo-8-quinoline). Cancer Lett. 2011, 312, 11-17. [CrossRef] [PubMed]

27. Sosić, I.; Mirković, B.; Arenz, K.; Stefane, B.; Kos, J.; Gobec, S. Development of New Cathepsin B Inhibitors: Combining Bioisosteric Replacements and Structure-Based Design To Explore the Structure-Activity Relationships of Nitroxoline Derivatives. J. Med. Chem. 2013, 56, 521-533. [CrossRef] [PubMed]

28. Knez, D.; Brus, B.; Coquelle, N.; Sosič, I.; Šink, R.; Brazzolotto, X.; Mravljak, J.; Colletier, J.P.; Gobec, S. Structure-based development of nitroxoline derivatives as potential multifunctional anti-Alzheimer agents. Bioorg. Med. Chem. 2015, 23, 4442-4452. [CrossRef] [PubMed]

29. Rotili, D.; Tomassi, S.; Conte, M.; Benedetti, R.; Tortorici, M.; Ciossani, G.; Valente, S.; Marrocco, B.; Labella, D.; Novellino, E.; et al. Pan-Histone Demethylase Inhibitors Simultaneously Targeting Jumonji C and Lysine-Specific Demethylases Display High Anticancer Activities. J. Med. Chem. 2013, 57, 42-55. [CrossRef] [PubMed]

30. Schiller, R.; Scozzafava, G.; Tumber, A.; Wickens, J.R.; Bush, J.T.; Rai, G.; Lejeune, C.; Choi, H.; Yeh, T.L.; Chan, M.C.; et al. A Cell-Permeable Ester Derivative of the JmjC Histone Demethylase Inhibitor IOX1. Chem. Med. Chem. 2014, 9, 566-571. [CrossRef] [PubMed]

31. Sliman, F.; Blairvacq, M.; Durieu, E.; Meijer, L.; Rodrigo, J.; Desmaële, D. Identification and structure-activity relationship of 8-hydroxy-quinoline-7-carboxylic acid derivatives as inhibitors of Pim-1 kinase. Bioorg. Med. Chem. Lett. 2010, 20, 2801-2805. [CrossRef] [PubMed]

32. Li, X.M.; Wood, T.E.; Sprangers, R.; Jansen, G.; Franke, N.E.; Mao, X.L.; Wang, X.M.; Zhang, Y.; Verbrugge, S.E.; Adomat, H.; et al. Effect of Noncompetitive Proteasome Inhibition on Bortezomib Resistance. J. Natl. Cancer Inst. 2010, 102, 1069-1082. [CrossRef] [PubMed]

33. Liu, Y.C.; Yang, Z.Y. Synthesis, crystal structure; antioxidation and DNA binding properties of binuclear Ho(III) complexes of Schiff-base ligands derived from 8-hydroxyquinoline-2-carboxyaldehyde and four aroylhydrazines. J. Inorg. Biochem. 2009, 103, 1014-1022. [CrossRef] [PubMed]

34. Jacobsen, J.A.; Fullagar, J.L.; Miller, M.T.; Cohen, S.M. Identifying Chelators for Metalloprotein Inhibitors Using a Fragment-Based Approach. J. Med. Chem. 2011, 54, 591-602. [CrossRef] [PubMed]

35. Shaw, A.Y.; Chang, C.Y.; Hsu, M.Y.; Lu, P.J.; Yang, C.N.; Chen, H.L.; Lo, C.W.; Shiau, C.W.; Chern, M.K. Synthesis and structure-activity relationship study of 8-hydroxyquinoline-derived Mannich bases as anticancer agents. Eur. J. Med. Chem. 2010, 45, 2860-2867. [CrossRef] [PubMed]

36. Ariyasu, S.; Sawa, A.; Morita, A.; Hanaya, K.; Hoshi, M.; Takahashi, I.; Wang, B.; Aoki, S. Design and synthesis of 8-hydroxyquinoline-based radioprotective agents. Bioorg. Med. Chem. 2014, 22, 3891-3905. [CrossRef] [PubMed] 
37. Cacciatore, I.; Fornasari, E.; Baldassarre, L.; Cornacchia, C.; Fulle, S.; Di Filippo, E.S.; Pietrangelo, T.; Pinnen, F. A Potent $(R)$-alpha-bis-lipoyl Derivative Containing 8-Hydroxyquinoline Scaffold: Synthesis and Biological Evaluation of Its Neuroprotective Capabilities in SH-SY5Y Human Neuroblastoma Cells. Pharmaceuticals 2013, 6, 54-69. [CrossRef] [PubMed]

38. Du Moulinet D'Hardemare, A.; Gellon, G.; Philouze, C.; Serratrice, G. Oxinobactin and Sulfoxinobactin; Abiotic Siderophore Analogues to Enterobactin Involving 8-Hydroxyquinoline Subunits: Thermodynamic and Structural Studies. Inorg. Chem. 2012, 51, 12142-12151. [CrossRef] [PubMed]

39. Fernández-Bachiller, M.I.; Pérez, C.; González-Munoz, G.C.; Conde, S.; López, M.G.; Villarroya, M.; García, A.G.; Rodriguez-Franco, M.I. Novel Tacrine-8-Hydroxyquinoline Hybrids as Multifunctional Agents for the Treatment of Alzheimer's Disease; with Neuroprotective; Cholinergic; Antioxidant; and Copper-Complexing Properties. J. Med. Chem. 2010, 53, 4927-4937. [CrossRef] [PubMed]

40. Calvaresi, E.C.; Hergenrother, P.J. Glucose conjugation for the specific targeting and treatment of cancer. Chem. Sci. 2013, 4, 2319-2333. [CrossRef] [PubMed]

41. Oliveri, V. New Glycoconjugates for the Treatment of Diseases Related to Metal Dyshomeostasis. ChemistryOpen 2015, 4, 792-795. [CrossRef] [PubMed]

42. Chan, S.H.; Chui, C.H.; Chan, S.W.; Kok, S.H.L.; Chan, D.; Tsoi, M.Y.T.; Leung, P.H.M.; Lam, A.K.Y.; Chan, A.S.C.; Lam, K.H.; et al. Synthesis of 8-Hydroxyquinoline Derivatives as Novel Antitumor Agents. ACS Med. Chem. Lett. 2012, 4, 170-174. [CrossRef] [PubMed]

43. Núñez, C.; Oliveira, E.; García-Prdo, J.; Diniza, M.; Lorenzof, J.; Capeloa, J.L.; Lodeiroa, C. A novel quinoline molecular probe and the derived functionalized gold nanoparticles: Sensing properties and cytotoxicity studies in MCF-7 human breast cancer cells. J. Inorg. Biochem. 2014, 137, 115-122. [CrossRef] [PubMed]

44. Kao, M.H.; Chen, T.Y.; Cai, Y.R.; Hu, C.H.; Liu, Y.W.; Jhong, Y.; Wu, A.T. A turn-on Schiff-base fluorescence sensor for $\mathrm{Mg}^{2+}$ ion and its practical application. J. Lumin. 2016, 169, 156-160. [CrossRef]

45. Zhang, H.R.; Meng, T.; Liu, Y.C.; Qin, Q.P.; Chen, Z.F.; Liu, Y.N.; Liang, H. Synthesis, Structure Characterization and Antitumor Activity Study of a New Iron(III) Complex of 5-Nitro-8-hydroxylquinoline (HNOQ). Chem. Pharm. Bull. 2016, 64, 1208-1217. [CrossRef] [PubMed]

46. Zhang, H.R.; Meng, T.; Liu, Y.C.; Chen, Z.F.; Liu, Y.N.; Liang, H. Synthesis, characterization and biological evaluation of a cobalt(II) complex with 5-chloro-8-hydroxyquinoline as anticancer agent. Appl. Organomet. Chem. 2016, 30, 740-747. [CrossRef]

47. Zhang, H.R.; Liu, Y.C.; Chen, Z.F.; Meng, T.; Zou, B.Q.; Liu, Y.N.; Liang, H. Studies on the structures, cytotoxicity and apoptosis mechanism of 8-hydroxylquinoline rhodium(III) complexes in T-24 cells. New J. Chem. 2016, 409, 6005-6014. [CrossRef]

48. Heidary, D.K.; Howerton, B.S.; Glazer, E.C. Coordination of Hydroxyquinolines to a Ruthenium bis-dimethyl-phenanthroline Scaffold Radically Improves Potency for Potential as Antineoplastic Agents. J. Med. Chem. 2014, 57, 8936-8946. [CrossRef] [PubMed]

49. Dömötör, O.; Pape, V.F.; May, N.V.; Szakács, G.; Enyedy, É.A. Comparative solution equilibrium studies of antitumor ruthenium( $\eta 6-p-c y m e n e)$ and rhodium( $\left(\eta-\mathrm{C}_{5} \mathrm{Me}_{5}\right)$ complexes of 8-hydroxyquinolines. Dalton Trans. 2017, 46, 4382-4396. [CrossRef] [PubMed]

50. Martín-Santos, C.; Michelucci, E.; Marzo, T.; Messori, L.; Szumlas, P.; Bednarski, P.J.; Mas-Ballesté, R.; Navarro-Ranninger, C.; Cabrer, S. Gold(III) complexes with hydroxyquinoline, aminoquinoline and quinoline ligands: Synthesis, cytotoxicity, DNA and protein binding studies. J. Inorg. Biochem. 2015, 153, 339-345. [CrossRef] [PubMed]

51. Qin, Q.P.; Chen, Z.F.; Qin, J.L.; He, X.J.; Li, Y.L.; Liu, Y.C.; Liang, H. Studies on antitumor mechanism of two planar platinum(II) complexes with 8-hydroxyquinoline: Synthesis, characterization, cytotoxicity, cell cycle and apoptosis. Eur. J. Med. Chem. 2015, 92, 302-313. [CrossRef] [PubMed]

52. Tardito, S.; Barilli, A.; Bassanetti, I.; Tegoni, M.; Bussolati, O.; Franchi-Gazzola, R.; Marchiò, L. Copper-Dependent Cytotoxicity of 8-Hydroxyquinoline Derivatives Correlates with Their Hydrophobicity and Does Not Require Caspase Activation. J. Med. Chem. 2012, 55, 10448-10459. [CrossRef] [PubMed]

53. Rogolino, D.; Cavazzoni, A.; Gatti, A.; Tegoni, M.; Pelosi, G.; Verdolino, V.; Carcelli, M. Anti-proliferative effects of copper(II) complexes with hydroxyquinoline-thiosemicarbazone ligands. Eur. J. Med. Chem. 2017, 128, 140-153. [CrossRef] [PubMed] 
54. Correia, I.; Adao, P.; Roy, S.; Wahba, M.; Matos, C.; Maurya, M.R.; Pessoa, J.C. Hydroxyquinoline derived vanadium (IV and $\mathrm{V}$ ) and copper(II) complexes as potential anti-tuberculosis and anti-tumor agents. J. Inorg. Biochem. 2014, 141, 83-93. [CrossRef] [PubMed]

55. Laplante, S.R.; Fader, L.D.; Fandrick, K.R.; Fandrick, D.R.; Hucke, O.; Kemper, R.; Miller, S.P.F.; Edwards, P.J. Assessing Atropisomer Axial Chirality in Drug Discovery and Development. J. Med. Chem. 2016, 54, 7005-7022. [CrossRef] [PubMed]

56. Sommerwerk, S.; Heller, L.; Kuhfs, J.; Csuk, R. Urea derivates of ursolic, oleanolic and maslinic acid induce apoptosis and are selective cytotoxic for several human tumor cell lines. Eur. J. Med. Chem. 2016, 119, 1-16. [CrossRef] [PubMed]

57. Ooi, K.K.; Yeo, C.I.; Mahandaran, T.; Ang, K.P.; Akim, A.M.; Cheah, Y.K.; Seng, H.L.; Tiekink, E.R. G 2 /M cell cycle arrest on HT-29 cancer cells and toxicity assessment of triphenylphosphanegold(I) carbonimidothioates, $\mathrm{Ph}_{3} \mathrm{PAu}[\mathrm{SC}(\mathrm{OR})=\mathrm{NPh}], \mathrm{R}=\mathrm{Me}$, Et, and iPr; during zebrafish development. J. Inorg. Biochem. 2017, 166, 173-181. [CrossRef] [PubMed]

58. Zhang, C.; Han, B.J.; Zeng, C.C.; Lai, S.H.; Li, W.; Tang, B.; Wan, D.; Jiang, G.B.; Liu, Y. Synthesis, characterization, in vitro cytotoxicity and anticancer effects of ruthenium(II) complexes on BEL-7402 cells. J. Inorg. Biochem. 2016, 157, 62-72. [CrossRef] [PubMed]

59. Zheng, C.P.; Liu, Y.N.; Liu, Y.; Qin, X.Y.; Zhou, Y.H.; Liu, J. Dinuclear ruthenium complexes display loop isomer selectivity to c-MYC DNA G-quadriplex and exhibit anti-tumour activity. J. Inorg. Biochem. 2016, 156, $122-132$. [CrossRef] [PubMed]

60. Yan, J.; Chen, J.; Zhang, S.; Hu, J.H.; Ling, H.; Li, X.S. Synthesis, Evaluation; and Mechanism Study of Novel Indole-Chalcone Derivatives Exerting Effective Antitumor Activity Through Microtubule Destabilization in Vitro and in Vivo. J. Med. Chem. 2016, 59, 5264-5283. [CrossRef] [PubMed]

61. Zhang, Y.L.; Qin, Q.P.; Cao, Q.Q.; Han, H.H.; Liu, Z.L.; Liu, Y.C.; Liang, H.; Chen, Z.F. Synthesis, crystal structure, cytotoxicity and action mechanism of a Rh(III) complex with 8-hydroxy-2-methylquinoline as a ligand. Med. Chem. Commun. 2017, 8, 184-190. [CrossRef]

62. Horvat, A.; Zorec, R.; Vardjan, N. Adrenergic stimulation of single rat astrocytes results in distinct temporal changes in intracellular Ca2+ and cAMP-dependent PKA responses. Cell Calcium 2016, 59, 156-163. [CrossRef] [PubMed]

63. Hu, X.Z.; Xu, Y.; Hu, D.C.; Hui, Y.; Yang, F.X. Apoptosis induction on human hepatoma cells Hep G2 of decabrominated diphenyl ether (PBDE-209). Toxicol. Lett. 2007, 171, 19-28. [CrossRef] [PubMed]

64. Kawiak, A.; Zawacka-Pankau, J.; Wasilewska, A.; Stasilojc, G.; Bigda, J.; Lojkowska, E. Induction of Apoptosis in HL-60 Cells through the ROS-Mediated Mitochondrial Pathway by Ramentaceone from Drosera aliciae. J. Nat. Prod. 2012, 75, 9-14. [CrossRef] [PubMed]

65. Spierings, D.; McStay, G.; Saleh, M.; Bender, C.; Chipuk, J.; Maurer, U.; Green, D.R. Connected to Death: The (Unexpurgated) Mitochondrial Pathway of Apoptosis. Science 2005, 310, 66-67. [CrossRef] [PubMed]

66. Qin, J.L.; Qin, Q.P.; Wei, Z.Z.; Yu, C.C.; Meng, T.; Wu, C.X.; Liang, Y.L.; Liang, H.; Chen, Z.F. Stabilization of c-myc G-Quadruplex DNA, inhibition of telomerase activity, disruption of mitochondrial functions and tumor cell apoptosis by platinum(II) complex with 9-amino-oxoisoaporphine. Eur. J. Med. Chem. 2016, 124, 417-427. [CrossRef] [PubMed]

67. Zhang, G.H.; Cai, L.J.; Wang, Y.F.; Zhou, Y.H.; An, Y.F.; Liu, Y.C.; Peng, Y.; Chen, Z.F.; Liang, H. Novel compound PS-101 exhibits selective inhibition in non-small-cell lung cancer cell by blocking the EGFR-driven antiapoptotic pathway. Biochem. Pharmacol. 2013, 86, 1721-1730. [CrossRef] [PubMed]

68. Chen, Z.F.; Qin, Q.P.; Qin, J.L.; Liu, Y.C.; Huang, K.B.; Li, Y.L.; Meng, T.; Zhang, G.H.; Peng, Y.; Luo, X.J.; et al. Stabilization of G-Quadruplex DNA, Inhibition of Telomerase Activity, and Tumor Cell Apoptosis by Organoplatinum(II) Complexes with Oxoisoaporphine. J. Med. Chem. 2015, 58, 2159-2179. [CrossRef] [PubMed]

69. Huang, K.B.; Chen, Z.F.; Liu, Y.C.; Xie, X.L.; Liang, H. Dihydroisoquinoline copper(II) complexes: Crystal structures, cytotoxicity, and action mechanism. RSC Adv. 2015, 5, 81313-81323. [CrossRef] 
70. Sheldrick, G.M. SHELXS-97, Program for Solution of Crystal Structures; University of Göttingen: Göttingen, Germany, 1997.

71. Qin, Q.P.; Qin, J.L.; Meng, T.; Yang, G.A.; Wei, Z.Z.; Liu, Y.C.; Liang, H.; Chen, Z.F. Preparation of 6/8/11-Amino/Chloro-Oxoisoaporphine and Group-10 Metal Complexes and Evaluation of Their in Vitro and in Vivo Antitumor Activity. Sci. Rep. 2016, 6, 37644. [CrossRef] [PubMed] 